\title{
Saint Peter and Saint Paul Archipelago barcoded: fish diversity in the remoteness and DNA barcodes reference library for metabarcoding monitoring
}

Marcelo Merten Cruz ( $\sim$ marcelomcruz4@gmail.com )

Universidade Federal do Rio Grande https://orcid.org/0000-0001-8374-5144

Lilian Sander Hoffmann

Universidade Federal do Rio Grande do Sul

Thales R. O. de Freitas

Universidade Federal do Rio Grande do Sul

\section{Research Article}

Keywords: Fish, DNA barcoding, Biodiversity, Metabarcoding, Conservation

Posted Date: September 28th, 2021

DOI: https://doi.org/10.21203/rs.3.rs-876354/v1

License: (c) (i) This work is licensed under a Creative Commons Attribution 4.0 International License.

Read Full License 


\section{Abstract}

Anthropogenic pressures have been depleting the global biodiversity. In order to monitor the changes in ecosystems, molecular techniques can be used to characterize species composition. Among molecular markers capable of identifying species, the $\mathrm{CO}$ is the most used, and its sequencing is the standard procedure of how taxonomic information can be surveyed. Despite this, new possibilities of biodiversity profiling have become possible through the assessment of highly fragmented DNA molecules in environmental samples. Now, medium- and short-length markers are used in metabarcoding studies. Here, a survey of marine fish from the Saint Peter and Saint Paul Archipelago was barcoded, in which the COI barcode procedure identified 21 species of 11 families of fish. Then, the first extensive COI library of these islands located in isolation was constructed; from these sequences, the most appropriate primer pair for future metabarcoding studies was identified. The new Saint Peter and Saint Paul sequence database has 9,183 sequences from 165 species and 62 families of fish. The overall mean distance among all sequences was 0.4 . This distance reveals that the archipelago is a reservoir of biodiversity as this attribute is higher than other islands around the world. Due to this, the protection of the archipelago should be enhanced and well monitored with science-based approaches such as DNA metabarcoding. In this case, the primer pair specifically designed from this library should be considered.

\section{Introduction}

Impacts of human-induced climate change, habitat fragmentation, and over-exploitation of natural resources have dramatically depleting global biodiversity, in special the marine environment (Díaz et al. 2006; Butchart et al. 2010; Pinsky et al. 2019). Conservation efforts based on robust biomonitoring programs are necessary to identify and mitigate ecological issues (Stat et al. 2017; Berry et al. 2019); therefore, life preservation diversity depends on species classification accuracy (Thomsen \& Willerslev 2015; Lin et al. 2020). The species composition and distribution can act as an environmental barometer of human activity (DiBattista et al. 2020).

Considering the dominant influence on mass extinctions that these activities have been occasioning, it was considered impossible to describe the true magnitude of the loss with traditional taxonomic approaches (Blaxter 2003; Hubert \& Hanner 2015); hence, molecular techniques have been developed to characterize species diversity quickly and reliably (Krishna Krishnamurthy \& Francis 2012; Elbrecht et al. 2019). The field was revolutionized when Hebert and collaborators (2003) proposed that standardized gene regions (DNA barcodes) could be used to identify and discriminate species (Hebert et al. 2003; Hebert, \& Gregory 2005).

In detail, the mitochondrial gene cytochrome c oxidase I (COI) is a key element in aerobic metabolism, thereby it is present in all animal species (Hebert et al. 2003). This 658-bp genetic fragment can be easily obtained from animal tissues, and once sequenced, it provides greater than $97 \%$ confidence for differentiating species by the divergence in their COI sequences (Hajibabaei et al. 2005; Meusnier et al. 
2008). After nearly two decades, the method has been widely accepted as the standard procedure for surveying biodiversity (Hubert \& Hanner 2015; Delrieu-Trottin et al. 2019).

During the same period of the DNA barcoding emergence, genetic sequencing tools had evolved at unprecedented speed (Zhang et al. 2011). Hence, modern high-throughput sequencing platforms have been made possible the quickly acquisition of large amounts of sequence data (Reuter, Spacek \& Snyder 2015). Conjointly, these technologies paved the way for a new field in biodiversity assessment, and now ecologists have the necessary tools to analyze the taxonomic composition of environmental samples (Taberlet et al. 2012; Creer et al. 2016).

The genetic assessment of multiple taxa from bulk environmental samples is denominated "DNA metabarcoding" (Taberlet et al. 2018); this approach is becoming a well-established tool for monitoring air, feces, sediment, soil, and water ecosystems (Creer et al. 2016; Jarman et al. 2018). With the aid of advanced molecular technologies, sensible DNA extraction protocols, and a massive parallel sequencing on Next-Generation sequencers, the DNA molecules expelled by organisms through urine, reproductive or digestive materials, hair, skin, tissues, and even from dead individuals in the environment are now able to be studied (Thomsen \& Willerslev 2015; Wangensteen et al. 2018).

However, the genetic material extracted from ecosystems is highly fragmented (Deagle, Eveson \& Jarman 2006); to this extent, it may be challenging in practice to retrieve the community COI barcodes genes from marine environmental sources (Meusnier et al. 2008). Metabarcoding analyses are contingent on target shorter (usually $<300$ base pairs) DNA regions than the traditionally defined barcoding regions (Yu et al. 2012; Clarke et al. 2014; Thomsen \& Willerslev 2015).

In this context, alternative target metabarcoding markers (metabarcodes) have been developed to obtain biodiversity information in short-length PCR products (Taberlet et al. 2018). The most promising metabarcodes for meiofaunal characterizations are the mitochondrial 12S or 16S rRNA genes (Epp et al. 2012). This is because the rRNA region folds to form a hairpin structure, so the respective mitochondrial region necessary for the translation is highly conserved, making the region a reliable method for the taxonomic assignment (Clarke et al. 2014; Yang et al. 2014).

Another metabarcode option is the much shorter sequence (130 bp) of $>650 \mathrm{bp}$ mitochondrial cytochrome c oxidase 1 (COI). The "mini-barcode" was tested in alignment with the full-length COI sequences. The results suggested that the region provides efficient taxonomic identification success, and their use was proposed to analyze environmental mixtures (Meusnier et al. 2008). However, the full core sequences cannot be retrieved by direct sequencing even when DNA targets are successfully amplified, which weakened the species identification capability (Sultana et al. 2018).

To overcome this limitation, medium-sized ( $>320 \mathrm{bp}$ ) barcodes were developed to identify fish species (Shokralla 2015; Günther et al. 2017; Sultana et al. 2018: Collins et al. 2019). For example, the use of medium-sized barcodes has demonstrated the capability to identify fish species even in processed forms and marine metabarcoding analyses (Shokralla 2015; Collins et al. 2019). Despite the successful use of 
these markers in fish biodiversity assessment via metabarcoding (McClenaghan et al. 2020; Singer et al. 2019; Russo et al. 2021), biodiversity assessments could be maximized by the use of regional-specific reference barcode libraries (Lin et al. 2020).

Customized libraries have greater importance in the case of marine fishes, because they have the role of bioindicators (Ribeiro et al. 2012; Brandão et al. 2016; Delrieu-Trottin 2019). To this extent, considering differences in marine ecosystems and the various habitat requirements for fauna survival, the assessment of fish richness, abundance, and diversity is a crucial indicator of the ecological characteristics of the region (Chovanec, Hofer \& Schiemer 2003).

In particular, oceanic islands are biogeographic regions in which species have evolved in isolation (Emerson 2002). This remoteness influence has shaped islands as an important reservoir of biological diversity and a refuge for many endemic species (Losos \& Ricklefs 2009; Shaw \& Gillespie 2016). For instance, physical, biological, and chemical features affect the fish assemblage structure (Andrades et al. 2018). In fact, the high level of fish endemism may claim the urgency in Brazil's island conservation (Andrades et al. 2018).

Saint Peter and Saint Paul Archipelago (SPSPA) is a small group of plutonic rocks uplifted from the upper mantle of the earth, located in the central equatorial Atlantic Ocean (Fig. 1) (Campos 2005). The archipelago is an important migratory, breeding, and feeding site for fishes (Mendonça et al. 2018). Also, its isolation spawned the evolution of the unique biodiversity of fishes, with a variety of color morphs and genetically divergent lineages (Pinheiro et al. 2020).

Fish biodiversity of SPSPA has been studied since Lubbock and Edwards (1981) listed 50 fish species. The authors surprisingly considered the species diversity the lowest of any tropical island studied to date. Following the inauguration of the first Archipelago's scientific station in 1998, scuba expeditions were made possible (Viana et al. 2009). Then, the number of registered species increased to 75 (Feitoza et al. 2003), to 116 (Vaske Jr et al. 2005), and most recently, to 225 species (Pinheiro et al. 2020). Contrary to the Lubbock and Edwards' (1981) considerations, the last survey pointed to the archipelago as the thirdhighest level of endemism in the Atlantic (Pinheiro et al. 2020). Among the 225 listed species, 112 are pelagic, 86 are shallow, and 27 are deep reef shore fishes. The inventory classification consists of 202 Teleostei distributed in 16 orders and 23 Elasmobranchii in 6 orders (Pinheiro et al. 2020).

Although remarkable for its biodiversity, the archipelago is not immune to ecological impacts from human activities. The massive fishing activity in their surroundings makes Saint Peter and Saint Paul's species extremely vulnerable, making the area the apical priority for biological study and conservation (Viana et al. 2015). In order to characterize the baselines of Saint Peter and Saint Paul's fish biodiversity, a survey of captured fishes has been genetically barcoded with COI. This study aims to provide the first extensive COI library of marine fish from SPSPA. Based on sequences of surveyed species and the ones listed in Pinheiro et al. (2020) retrieved from BOLD, the most appropriate primer pair for future metabarcoding studies have pointed. 


\section{Materials And Methods}

The field expeditions were conducted between 2004 and 2015 in surroundings of the Saint Peter and Saint Paul Archipelago $\left(000^{\circ} 55^{\prime} \mathrm{N}\right.$ and $\left.029^{\circ} 21^{\prime} \mathrm{W}\right)$. Fishes were randomly caught by an authorized fisherman (license number SISBIO/ICMBio 014/2005). Tissue fragments were labeled (numbered) and preserved in $96 \%$ ethanol at $-20^{\circ} \mathrm{C}$ until their extraction.

DNA was extracted using the PureLink ${ }^{\text {TM }}$ Genomic DNA Mini Kit (Thermo Fisher Scientific) following the manufacturer's protocol. The forward and reverse "Fish" primer pair (Ward et al. 2005) was used to amplify the cytochrome $c$ oxidase subunit $\mathrm{i}(\mathrm{COI})$ gene by polymerase chain reaction (PCR). Each PCR was conducted in a total volume of $25 \mu \mathrm{L}$ reaction mix consisting of $0.2 \mathrm{mM}$ of dNTPs, buffer $1 \times, 1.5 \mathrm{mM}$ of $\mathrm{MgCl} 2,0.2 \mu \mathrm{M}$ of each primer, $1 \mathrm{U}$ of Taq polymerase, 50-100 $\mathrm{ng}$ of template DNA, and ultrapure water to a final volume. The thermal cycling condition began with an initial denaturing at $94^{\circ} \mathrm{C}$ for 5 minutes, followed by 35 repeated cycles of denaturing $\left(94^{\circ} \mathrm{C}\right.$ for 0.5 minutes), annealing $\left(50^{\circ} \mathrm{C}\right.$ for 0.5 minutes) and extension $\left(72^{\circ} \mathrm{C}\right.$ for 1 minute), then concluded with a final extension at $72^{\circ} \mathrm{C}$ for 7 minutes. The size and specificity of amplification products were confirmed in $1 \%$ agarose stained with GelRed (Biotium, Fremont, California). The successful products were purified using exonuclease I and Shrimp Alkaline Phosphatase enzymes. Finally, they were sequenced by the Sanger method on an ABI3730XL DNA sequencer (Thermo Fischer Scientific, Massachusetts, United States), with the forward primer used for amplification.

The generated sequences were edited in Geneious Pro version 9 software and aligned using ClustalW (Edgar 2004) in Geneious software. Species were identified using the "Identification Engine" of the Barcode of Life Data System (BOLD). The taxonomic identity of each sequence was assigned to the deposited sequence with the highest similarity score. Also, a neighbor-joining tree was constructed based on the aligned dataset using the Kimura 2-Parameter (K2P) model (Kimura 1980) with 1,000 bootstrap replicates and pairwise deletion in Geneious to estimate the phylogenetic relationship between species. 
Table 1

Sample identification, identified species, their family and similarity to the BOLD Database candidate species (\%).

\begin{tabular}{|c|c|c|c|}
\hline Sample Identification & Candidate Species name & Family & Identity (\%) \\
\hline 1 & Canthidermis maculata & Balistidae & 98.04 \\
\hline 2 & Ginglymostoma cirratum & Ginglymostomatidae & 100 \\
\hline 3 & Thunnus atlanticus & Scombridae & 99.84 \\
\hline 4 & Acanthocybium solandri & Scombridae & 100 \\
\hline 5 & Coryphaena hippurus & Coryphaenidae & 100 \\
\hline 6 & Carcharhinus falciformis & Carcharhinidae & 100 \\
\hline 7 & Canthidermis maculata & Balistidae & 100 \\
\hline 8 & Caranx bartholomaei & Carangidae & 100 \\
\hline 9 & Xiphias gladius & Xiphiidae & 100 \\
\hline 10 & Canthidermis maculata & Balistidae & 100 \\
\hline 11 & Thryssa chefuensis & Coryphaenidae & 100 \\
\hline 12 & Sphyrna lewini & Sphyrnidae & 100 \\
\hline 13 & Carcharhinus limbatus & Carcharhinidae & 100 \\
\hline 14 & Acanthocybium solandri & Scombridae & 100 \\
\hline 15 & Cheilopogon atrisignis & Exocoetidae & 100 \\
\hline 16 & Remora brachyptera & Echeneidae & 100 \\
\hline 17 & Sphyrna zygaena & Sphyrnidae & 100 \\
\hline 18 & Xiphias gladius & Xiphiidae & 100 \\
\hline 19 & Prionace glauca & Carcharhinidae & 100 \\
\hline 20 & Caranx lugubris & Carangidae & 100 \\
\hline 21 & Canthidermis maculata & Balistidae & 100 \\
\hline 22 & Elagatis bipinnulata & Xiphiidae & 100 \\
\hline 23 & Remora australis & Echeneidae & 100 \\
\hline 24 & Halichoeres radiatus & Labridae & 100 \\
\hline 25 & Cheilopogon nigricans & Exocoetidae & 100 \\
\hline 26 & Prionace glauca & Carcharhinidae & 100 \\
\hline
\end{tabular}


COI reference database from Saint Peter and Saint Paul fish species was developed based on sequences of surveyed species, as well as the ones listed in Pinheiro et al. (2020). All available COI sequences were downloaded from BOLD (accessed 15 June 2021). A detailed list of specimens and their BOLD IDs is given in Table 1, then overall mean distance by (K2P) was computed using MEGAX software.

A new primer pair exclusively curated for this database was designed in Primer3 software. The performance of the newly designed primers was tested in silico against Saint Peter and Saint Paul fish sequences repository for future metabarcoding studies.

All graphics and figures were created and edited using Adobe Illustrator.

\section{Results}

The extraction and amplification methods were successful for 26 of 28 samples. Among the 26 samples, the COI Barcode could be identified on BOLD, with a high percentage of similarity (98.04\%-100\%) (Table 1), revealing 21 species that are found in 11 families of fishes (Figure 2). Among the 21 species of fish, Canthidermis maculate was the most abundant (3 of the samples), followed by Acanthocybium solandri, Xiphias gladius, and Prionace glauca (two samples each).

165 of the 225 confirmed taxa listed in Pinheiro et al. (2020) have their sequences deposited in the BOLD database; therefore, the new Saint Peter and Saint Paul sequence database have 9183 sequences from 165 species and 62 families of fish. The overall mean distance among all sequences was 0.4 .

From this database was designed a new primer marker suited to amplify a product size of 262 base pairs of $\mathrm{COI}$ region. The new primer pair performs in silico capacity to amplify $73.6 \%$ of Saint Peter and Saint Paul's sequences.

\section{Discussion}

\section{Biodiversity of SPSPA:}

Along the floor of the Atlantic Ocean are located the largest geological features on the planet. An immensely long mountain range developed due to the divergent motion between continental plates, the Mid-Atlantic Ridge (Searle 2013; UNESCO 2021). Situated between Brazil and the African continent, the Saint Peter and Saint Paul Archipelago is a rare non-volcanic formation resulting from the Mid-Atlantic Ridge's exhumed mantle rocks (Mohriak 2020). As a consequence of unique geological traits, along with latitude, weather, marine currents, and biogeographic features the biodiversity of the SPSPA is commensurately singular.

As expected from the theory of island biogeography, the site represents an important reservoir of biological diversity and a refuge for many endemic species that have diversified on these islands through 
time (MacArthur \& Wilson 1967; Pinheiro et al. 2017). However, it seems that the biodiversity of SPSPA is even more remarkable, as the average K2P distance of individuals within species found in this study was higher than other islands around the world (Ward et al. 2005; Rock et al. 2008; Zhang \& Hanner 2011; Steinke et al. 2017; Bingpeng et al. 2018; Xu et al. 2019).

Naturally, the isolation has been played a crucial role in the genetic diversity and endemism of the smallest remote tropical island in the world (Luiz et al. 2015). Aside from the distance, it was the seamounts that may have played an essential function in the marine evolution of the SPSPA, the site (as a peak of the mountain range) acted as a "stepping stone" for fishes during successive periods of sealevel changes (Ludt \& Rocha 2015; Dias et al. 2019). Also, it is the SPSPA topography and strategic location that have been guaranteeing the rocks as an important feeding and reproduction ground for several migratory pelagic species, mostly with high commercial value, such as the yellowfin tuna (Thunnus albacares); the wahoo (Acanthocybium solandri); the rainbow runner (Elagatis bipinnulata); the flying fish (Cheilopogon cyanopterus); whale shark (Rhincodon typus); silky shark (Carcharhinus falciformis); and Galapagos shark (Carcharhinus galapagensis) (Hazin et al. 2008; Viana et al. 2015; Pimentel et al. 2020). Due to the heterogeneity of migrants and residents of the region, molecular techniques are a useful tool to catalogue and uncover the biodiversity of SPSPA.

\section{DNA Barcoding}

DNA barcoding technology has been elucidated the global diversity to provide an efficient molecular technique for species identification (Hebert et al. 2003; Krishna Krishnamurthy \& Francis 2012). The mitochondrial COI gene has been barcoding fish species with high efficiency (Ward 2012; Ward et al. 2009). The marine ichthyofauna was successfully characterized in Australia (Ward et al. 2005), Antarctic (Rock et al. 2008; Mabragaña et al. 2016), Canada (Steinke et al. 2009), the Arctic (Mecklenburg et al. 2010), Japan (Zhang \& Hanner 2011), India (WS et al. 2011), Portugal (Costa et al. 2012), Brazil (Ribeiro et al. 2012), Germany (Knebelsberger et al. 2014), Taiwan (Bingpeng et al. 2018), Indonesia (Limmon et al. 2020), Pakistan (Ghouri et al. 2020), and Bangladesh (Ahmed et al. 2021).

In this study, the authors successfully amplified the COI barcode sequences for Saint Peter and Saint Paul Archipelago fishes. The surveyed site is a remote and protected oceanic island (Soares \& Lucas 2018). Naturally, the sample size is limited; for this reason the samples of this study were opportunistically collected over different expeditions. Aside from the sampling challenges, the COI barcoding gene of 26 fish species were successfully amplified. The differentiation between species through individual COI barcodes validates the efficiency of $\mathrm{COI}$ barcodes for identifying marine fish species.

Among the sequences, the AT content (56.30\%) was higher than the GC content (43.70\%), which is congruent with the constructed SPSPA fish database (AT content: $55.70 \%$ ) and other COI barcoding of marine fish studies (Ward et al. 2005; Steinke et al. 2009; Mecklenburg et al. 2010; Zhang \& Hanner 2011; WS et al. 2011; Costa et al. 2012; Ribeiro et al. 2012; Knebelsberger et al. 2014; Bingpeng et al. 2018; Limmon et al. 2020; Ghouri et al. 2020; Ahmed et al. 2021). Also, the constructed Neighbor-Joining tree clustered with coherency closely related species under the same nodes, while dissimilar species were 
clustered under separate nodes. The identification of surveyed species via COI barcoding was valuable not only to bio-scan the fishes of Saint Peter and Saint Paul, but also to reveal an uncovered diversity of the site.

\section{New species records for the site:}

The database of the fish biodiversity of SPSPA constructed by Pinheiro et al (2020) includes data from expeditions of the shallow and deep reefs of SPSPA and a compilation of records from the literature from almost four decades of study. Apart from this extensive work, our survey opened up the possibility of uncovering the hidden biodiversity of the rocks.

The feasibility of new records for the region is sustained by the fact that the DNA barcoding revolution has hastened species discovery during the last 15 years (Cao et al. 2016; DeSalle \& Goldstein 2019; Lopez-Vaamonde et al. 2021). In turn, efforts to collect and barcode fish species from specific regions aided new fish records in other regions of the globe (Steinke et al. 2017; Ahmed et al. 2021).

The methodology applied in this study revealed four new records to Saint Peter and Saint Paul region: Cheilopogon atrisignis; Cheilopogon nigricans; Remora australis; and Thryssa chefuensis. Considering the natural history of these species, it is plausible that Cheilopogon nigricans and Remora australis inhabit the SPSPA, as their distribution is described to be in the neighboring waters of the Atlantic Ocean (Fishbase 2021). Whileas, Cheilopogon atrisignis and Thryssa chefuensis are related to the Indian and Pacific oceans respectively (Fishbase 2021). Additional morphometric approaches must be applied in order to confirm the presence of these four species in SPSPA, by any means this shows there is yet diversity to be discovered in this portion of the ocean and their protection ought to be ensured.

\section{Future monitoring and conservation considerations:}

Due to the presence and connectivity of key species of corals, crustaceans, mollusks, fishes, marine birds, and cetaceans SPSPA is protected by the Ministry of the Environment of Brazil since 1986 (Francini-Filho et al. 2018). Despite the protection, commercial fishing boats were allowed to operate in the SPSPA regularly (Viana et al. 2015). In 2018, the environmental protection of the islands and surroundings was increased by the Brazilian government (Brazil 2021). However, the vast majority of the new areas is "Area of Sustainable Use", where "subsistence" fisheries are allowed specifically in its management plan; it turned out not being subsistence fishery and culminated in truly commercial fishing and industrial activities from regional fishing companies as reported by Giglio et al. (2018). Furthermore, the habitats considered more vulnerable with high environmental impact have not received integral protection. The areas of integral protection were designated in places where these activities are already unlikely or rare (Magris \& Pressey 2018).

Depth knowledge and studies are crucial to define boundaries and to set goals for Marine Protected Areas. Therefore, systematic data collection along time and space is necessary to understand the protected ecosystem better and promote possible zoning changes. Considering the richness of SPSPA 
biodiversity and their lack of protection, advanced genetics tools for monitoring ecosystems are needed. In this case, DNA metabarcoding of marine water has the potential to effectively monitor and give solid periodic information to managers and policymakers (Gold et al. 2021).

With special regard to SPSPA fishes, this study provided a reliable DNA barcodes reference library for future metabarcoding identifications. Also, by analyzing all 9,183 sequences, a primer pair able to amplify a short region of DNA was pointed, as ideally stipulated for metabarcoding analyses (Taberlet et al. 2018). The indicated marker is capable to amplify most of the fish species on the range in that library. This is because fishes are the largest group of vertebrates, and the teleost and elasmobranch species are evolutionarily distant, therefore their genetic fingerprints are dissimilar (Nelson et al. 2016). A cocktail of primers should be considered for a comprehensive metabarcoding study of the total fish biodiversity of the region (Collins et al. 2019).

\section{Conclusion}

The Saint Peter and Saint Paul Archipelago is a reservoir of biodiversity. The strategic location of the rocks is an important feeding and reproductive ground for a variety of migratory fishes; likewise, it is a refuge to the third-highest fish endemism level in the Atlantic. The checklist of fishes that live in shallow and deep waters has already elucidated these outstanding patterns (Pinheiro et al. 2020); as yet, the genetic signatures of SPSPA fish species have remained unknown. Thereupon, this research endeavored to barcode surveyed species of the site and catalog all deposited sequences of listed fishes in the region. Then, it was discovered that SPSPA fishes are even more distinct from other islands around the world. Due to this, the protection of the archipelago should be enhanced and well-monitored with science-based approaches. In this case, DNA metabarcoding is an emerging tool that could assist in safeguarding SPSPA fauna; therefore, the reference library and the primer pair specifically designed to study the fishes of these islands should be considered for future metabarcoding monitoring activities.

\section{Declarations}

\section{Funding Information}

This work was funded by the Programa Arquipélago e llhas Oceânicas (Grant Number \#56/2005, \#26/2009, and 39/2012). Also, this work was supported by the the Brazilian Navy (SECIRM); Federal University of Rio Grande do Sul (UFRGS); The Brazilian Agency of the Coordination for Improvement of Higher Education Personnel (CAPES); the National Council for Scientific and Technological Development (CNPq), and the Research Support Foundation of the State of Rio Grande do Sul (FAPERGS).

\section{Acknowledgements}

Concerning the samples, the authors would like to express their gratitude to the fishermen of Transmar I and II for their help and their support. 


\section{Competing Interests}

The authors declare that there are no competing interests.

\section{Data Archiving}

The sequences were deposited in GenBank under accession numbers OK030800-OK030825. The datasets that were generated during the current study are available from the corresponding author upon reasonable request. All of the data that was generated or analyzed during this study is included in this published article. Readers are welcome to comment on the online version of the paper.

\section{References}

Ahmed, Md. S., Datta, S. K., Saha, T., \& Hossain, Z. (2021). Molecular characterization of marine and coastal fishes of Bangladesh through DNA barcodes. Ecology and Evolution, 11(9), 3696-3709. https://doi.org/10.1002/ECE3.7355

Andrades, R., Reis-Filho, J.A., Macieira, R.M. et al. (2018). Endemic fish species structuring oceanic intertidal reef assemblages. Sci Rep 8, 10791. https://doi.org/10.1038/s41598-018-29088-0

Berry, T. E., Saunders, B. J., Coghlan, M. L., Stat, M., Jarman, S., Richardson, A. J., ... \& Bunce, M. (2019). Marine environmental DNA biomonitoring reveals seasonal patterns in biodiversity and identifies ecosystem responses to anomalous climatic events. PLoS genetics, 15(2), e1007943. https://doi.org/10.1371/journal.pgen.1007943

Bingpeng, X., Heshan, L., Zhilan, Z., Chunguang, W., Yanguo, W., \& Jianjun, W. (2018). DNA barcoding for identification of fish species in the Taiwan Strait. PLOS ONE, 13(6), e0198109.

https://doi.org/10.1371/JOURNAL.PONE.0198109

Blaxter, M. (2003). Counting angels with DNA. Nature 421, 122-123. https://doi.org/10.1038/421122a

Brandão, J. H. S. G., de Araújo Bitencourt, J., Santos, F. B., Watanabe, L. A., Schneider, H., Sampaio, I., \& de Mello Affonso, P. R. A. (2016). DNA barcoding of coastal ichthyofauna from Bahia, northeastern Brazil, South Atlantic: high efficiency for systematics and identification of cryptic diversity. Biochemical Systematics and Ecology, 65, 214-224. https://doi.org/10.1016/j.bse.2016.02.012

Brazil. (2021). Instituto Chico Mendes de Conservação da Biodiversidade - Brasil cria quatro novas unidades marinhas. Retrieved July 21, 2021, from https://www.icmbio.gov.br/portal/ultimas-noticias/20geral/9509-brasil-cria-quatro-novas-unidades-marinhas.

Butchart, S. H., Walpole, M., Collen, B., van Strien, A., Scharlemann, J. P., Almond, R. E., Baillie, J. E., Bomhard, B., Brown, C., Bruno, J., Carpenter, K. E., Carr, G. M., Chanson, J., Chenery, A. M., Csirke, J., Davidson, N. C., Dentener, F., Foster, M., Galli, A., Galloway, J. N., ... Watson, R. (2010). Global biodiversity: 
indicators of recent declines. Science (New York, N.Y.), 328(5982), 1164-1168.

https://doi.org/10.1126/science.1187512

Cao, X., Liu, J., Chen, J., Zheng, G., Kuntner, M., \& Agnarsson, I. (2016). Rapid dissemination of taxonomic discoveries based on DNA barcoding and morphology. Scientific Reports 2016 6:1, 6(1), 1-13. https://doi.org/10.1038/srep37066

Campos, T. F., Neto, J. V., Srivastava, N. K., Petta, R. A., Hartmann, L. A., Moraes, J. F. S., ... \& Silveira, S. R. M. (2005). Saint Peter and Saint Paul's archipelago-tectonic uplift of infra-crustal rocks in the Atlantic Ocean. Geological and Paleontological Sites of Brazil. (Available at http://sigep.cprm.gov.br/sitio002/sitio002english.pdf).

Chovanec, A., Hofer, R., \& Schiemer, F. (2003). Fish as bioindicators. In Trace metals and other contaminants in the environment (Vol. 6, pp. 639-676). Elsevier.

Clarke, L. J., Soubrier, J., Weyrich, L. S., \& Cooper, A. (2014). Environmental metabarcodes for insects: in silico PCR reveals potential for taxonomic bias. Molecular ecology resources, 14(6), 1160-1170. https://doi.org/10.1111/1755-0998.12265

Collins, RA, Bakker, J, Wangensteen, OS, et al. (2019). Non-specific amplification compromises environmental DNA metabarcoding with COI. Methods Ecol Evol. 2019; 10: 1985- 2001. https://doi.org/10.1111/2041-210X.13276

Costa, F. O., Landi, M., Martins, R., Costa, M. H., Costa, M. E., Carneiro, M., Alves, M. J., Steinke, D., \& Carvalho, G. R. (2012). A Ranking System for Reference Libraries of DNA Barcodes: Application to Marine Fish Species from Portugal.PLOSONE, 7 (4) , e35858. https://doi.org/ 10.1371/journal.pone.0035858

Creer, S., Deiner, K., Frey, S., Porazinska, D., Taberlet, P., Thomas, W.K., Potter, C. and Bik, H.M. (2016). The ecologist's field guide to sequence-based identification of biodiversity. Methods Ecol Evol, 7: 1008-1018. https://doi.org/10.1111/2041-210X.12574

Deagle, B. E., Eveson, J. P., \& Jarman, S. N. (2006). Quantification of damage in DNA recovered from highly degraded samples-a case study on DNA in faeces. Frontiers in zoology, 3, 11. https://doi.org/10.1186/1742-9994-3-11

Delrieu-Trottin, E., Williams, J. T., Pitassy, D., Driskell, A., Hubert, N., Viviani, J., ... \& Planes, S. (2019). A DNA barcode reference library of French Polynesian shore fishes. Sci Data. 6(1):114. https://doi.org/10.1038/s41597-019-0123-5

DeSalle, R., \& Goldstein, P. (2019). Review and Interpretation of Trends in DNA Barcoding. Frontiers in Ecology and Evolution, 0, 302. https://doi.org/10.3389/FEV0.2019.00302

Dias, R. M., Lima, S. M. Q., Mendes, L. F., Almeida, D. F., Paiva, P. C., \& Britto, M. R. (2019). Different speciation processes in a cryptobenthic reef fish from the Western Tropical Atlantic. Hydrobiologia 2019 
837:1, 837(1), 133-147. https://doi.org/10.1007/S10750-019-3966-Z

Díaz S, Fargione J, Chapin FS III, Tilman D. (2006). Biodiversity Loss Threatens Human Well-Being. PLoS Biol 4(8): e277. https://doi.org/10.1371/journal.pbio.0040277

DiBattista, J.D., Reimer, J.D., Stat, M. et al. (2020). Environmental DNA can act as a biodiversity barometer of anthropogenic pressures in coastal ecosystems. Sci Rep 10, 8365 https://doi.org/10.1038/s41598020-64858-9

Elbrecht V, Braukmann TWA, Ivanova NV, Prosser SWJ, Hajibabaei M, Wright M, Zakharov EV, Hebert PDN, Steinke D. (2019). Validation of COI metabarcoding primers for terrestrial arthropods. PeerJ 7:e7745 https://doi.org/10.7717/peerj.7745

Emerson B. C. (2002). Evolution on oceanic islands: molecular phylogenetic approaches to understanding pattern and process. Molecular ecology, 11(6), 951-966. https://doi.org/10.1046/j.1365-

294x.2002.01507.x

Epp, L. S., Boessenkool, S., Bellemain, E. P., Haile, J., Esposito, A., Riaz, T., Erséus, C., Gusarov, V. I., Edwards, M. E., Johnsen, A., Stenøien, H. K., Hassel, K., Kauserud, H., Yoccoz, N. G., Bråthen, K. A., Willerslev, E., Taberlet, P., Coissac, E., \& Brochmann, C. (2012). New environmental metabarcodes for analysing soil DNA: potential for studying past and present ecosystems. Molecular ecology, 21(8), 18211833. https://doi.org/10.1111/j.1365-294X.2012.05537.x

Feitoza, B. M., Rocha, L. A., Luis-Júnior, O. J., Floeter, S. R., \& Gasparini, J. L. (2003). Reef fishes of St. Paul's Rocks: New records and notes on biology and zoogeography. Aqua, Journal of Ichthyology and Aquatic Biology, 7, 61-82.

Francini-Filho, R. B., Ferreira, C. E. L., Mello, T. J., Prates, A. P. L., \& Silva, V. N. (2018). Diagnóstico Biológico e Socioeconômico para a proposta de criação de uma área de Proteção Ambiental (APA) e um Monumento Natural Marinho (MONA) no Arquipélago São Pedro e São Paulo. Governo Brasileiro. Ministério do Meio Ambiente.

Froese, R. and D. Pauly. Editors. 2021. FishBase. World Wide Web electronic publication. www.fishbase.org, version (06/2021)

Ghouri, M. Z., Ismail, M., Javed, M. A., Khan, S. H., Munawar, N., Umar, A. bin, Mehr-un-Nisa, Aftab, S. O., Amin, S., Khan, Z., \& Ahmad, A. (2020). Identification of Edible Fish Species of Pakistan Through DNA Barcoding. Frontiers in Marine Science, 0, 868. https://doi.org/10.3389/FMARS.2020.554183

Giglio, V. J., Pinheiro, H. T., Bender, M. G., Bonaldo, R. M., Costa-Lotufo, L. v., Ferreira, C. E. L., Floeter, S. R., Freire, A., Gasparini, J. L., Joyeux, J. C., Krajewski, J. P., Lindner, A., Longo, G. O., Lotufo, T. M. C., Loyola, R., Luiz, O. J., Macieira, R. M., Magris, R. A., Mello, T. J., ... Francini-Filho, R. B. (2018). Large and remote 
marine protected areas in the South Atlantic Ocean are flawed and raise concerns: Comments on Soares and Lucas (2018). Marine Policy, 96, 13-17. https://doi.org/10.1016/J.MARPOL.2018.07.017

Günther, B., Raupach, M. J., \& Knebelsberger, T. (2017). Full-length and mini-length DNA barcoding for the identification of seafood commercially traded in Germany. Food Control, 73, 922-929.

https://doi.org/10.1016/j.foodcont.2016.10.016

Gold, Z., Sprague, J., Kushner, D. J., Marin, E. Z., \& Barber, P. H. (2021). eDNA metabarcoding as a biomonitoring tool for marine protected areas. PLOS ONE, 16(2), e0238557.

https://doi.org/10.1371/JOURNAL.PONE.0238557

Hajibabaei, M., deWaard, J. R., Ivanova, N. V., Ratnasingham, S., Dooh, R. T., Kirk, S. L., Mackie, P. M., \& Hebert, P. D. (2005). Critical factors for assembling a high volume of DNA barcodes. Philosophical transactions of the Royal Society of London. Series B, Biological sciences, 360(1462), 1959-1967. https://doi.org/10.1098/rstb.2005.1727

Hazin, F., Vaske Júnior, T., Oliveira, P., Macena, B., \& Carvalho, F. (2008). Occurrences of whale shark (Rhincodon typus Smith, 1828) in the Saint Peter and Saint Paul archipelago, Brazil. Brazilian Journal of Biology, 68(2), 385-389. https://doi.org/10.1590/S1519-69842008000200021

Hebert, P. D., Cywinska, A., Ball, S. L., \& deWaard, J. R. (2003). Biological identifications through DNA barcodes. Proceedings. Biological sciences, 270(1512), 313-321.

https://doi.org/10.1098/rspb.2002.2218

Hebert, P. D., \& Gregory, T. R. (2005). The promise of DNA barcoding for taxonomy. Systematic biology, 54(5), 852-859. https://doi.org/10.1080/10635150500354886

Hubert, N., Hanner, R. (2015). DNA Barcoding, species delineation and taxonomy: a historical perspective. DNA Barcodes 3: 44-58. https://doi.org/10.1515/dna-2015-0006

Jarman, S. N., Berry, O., \& Bunce, M. (2018). The value of environmental DNA biobanking for long-term biomonitoring. Nature ecology \& evolution, 2(8), 1192-1193. https://doi.org/10.1038/s41559-018-0614-3

Kimura M. (1980). A simple method for estimating evolutionary rates of base substitutions through comparative studies of nucleotide sequences. Journal of molecular evolution, 16(2), 111-120. https://doi.org/10.1007/BF01731581

Knebelsberger, T., Landi, M., Neumann, H., Kloppmann, M., Sell, A. F., Campbell, P. D., Laakmann, S., Raupach, M. J., Carvalho, G. R., \& Costa, F. O. (2014). A reliable DNA barcode reference library for the identification of the North European shelf fish fauna. Molecular Ecology Resources, 14(5), 1060-1071. https://doi.org/10.1111/1755-0998.12238

Krishna Krishnamurthy, P., Francis, R.A. (2012). A critical review on the utility of DNA barcoding in biodiversity conservation. Biodivers Conserv 21, 1901-1919 https:// doi.org/10.1007/s10531-012-0306-2 
Lakra, W. S., Verma, M. S., Goswami, M. et al. (2011). DNA barcoding Indian marine fishes. Molecular Ecology Resources, 11(1), 60-71. https://doi.org/10.1111/J.1755-0998.2010.02894.X

Leray, M., Yang, J.Y., Meyer, C.P. et al. (2013). A new versatile primer set targeting a short fragment of the mitochondrial $\mathrm{COI}$ region for metabarcoding metazoan diversity: application for characterizing coral reef fish gut contents. Front Zool 10, 34. https://doi.org/10.1186/1742-9994-10-34

Limmon, G., Delrieu-Trottin, E., Patikawa, J., Rijoly, F., Dahruddin, H., Busson, F., Steinke, D., \& Hubert, N. (2020). Assessing species diversity of Coral Triangle artisanal fisheries: A DNA barcode reference library for the shore fishes retailed at Ambon harbor (Indonesia). Ecology and Evolution, 10(7), 3356-3366. https://doi.org/10.1002/ECE3.6128

Lin, X-L, Mo, L, Bu, W-J, Wang, X-H. (2020). The first comprehensive DNA barcode reference library of Chinese Tanytarsus (Diptera: Chironomidae) for environmental DNA metabarcoding. Divers Distrib.; 00: 1- 10. https://doi.org/10.1111/ddi.13209

Losos, J. B., \& Ricklefs, R. E. (2009). Adaptation and diversification on islands. Nature, 457(7231), 830836. https://doi.org/10.1038/nature07893

Lubbock, R. and Edwards, A. (1981). The fishes of Saint Paul's Rocks. Journal of Fish Biology, 18: 135157. https://doi.org/10.1111/j.1095-8649.1981.tb02810.x

Ludt, W. B., \& Rocha, L. A. (2015). Shifting seas: the impacts of Pleistocene sea-level fluctuations on the evolution of tropical marine taxa. Journal of Biogeography, 42(1), 25-38.

https://doi.org/10.1111/JBI.12416

Luiz, O. J., Mendes, T. C., Barneche, D. R., Ferreira, C. G., Noguchi, R., Villaça, R. C., ... \& Ferreira, C. E. (2015). Community structure of reef fishes on a remote oceanic island (St Peter and St Paul's Archipelago, equatorial Atlantic): the relative influence of abiotic and biotic variables. Marine and Freshwater Research, 66(8), 739-749. https://doi.org/10.1071/MF14150

Mabragaña, E., Delpiani, S. M., Rosso, J. J., González-Castro, M., Antoni, M. D., Hanner, R., \& Astarloa, J. M. D. de. (2016). Barcoding Antarctic Fishes: Species Discrimination and Contribution to Elucidate Ontogenetic Changes in Nototheniidae. DNA Barcoding in Marine Perspectives: Assessment and Conservation of Biodiversity, 213-242. https://doi.org/10.1007/978-3-319-41840-7_14

MacArthur, R. H. \& Wilson, E. O. The Theory of Island Biogeography (Princeton Univ. Press, 1967)

Magris, R. A., \& Pressey, R. L. (2018). Marine protected areas: Just for show?. Science (New York, N.Y.), 360(6390), 723-724. https://doi.org/10.1126/science.aat6215

McClenaghan B, Fahner N, Cote D, Chawarski J, McCarthy A, Rajabi H, et al. (2020). Harnessing the power of eDNA metabarcoding for the detection of deep-sea fishes. PLoS ONE 15(11): e0236540. https://doi.org/10.1371/journal.pone.0236540 
Mecklenburg, C. W., Møller, P. R., \& Steinke, D. (2010). Biodiversity of arctic marine fishes: taxonomy and zoogeography. Marine Biodiversity 2010 41:1, 41(1), 109-140. https://doi.org/10.1007/S12526-0100070-Z

Mendonça, S. A., Macena, B., Afonso, A. S., \& Hazin, F. (2018). Seasonal aggregation and diel activity by the sicklefin devil ray Mobula tarapacana off a small, equatorial outcrop of the Mid-Atlantic Ridge. Journal of fish biology, 93(6), 1121-1129. https://doi.org/10.1111/jfb.13829

Meusnier, I., Singer, G.A., Landry, JF. et al. (2008). A universal DNA mini-barcode for biodiversity analysis. BMC Genomics 9, 214 https://doi.org/10.1186/1471-2164-9-214

Mohriak, W. (2020). Genesis and evolution of the South Atlantic volcanic islands offshore Brazil. GeoMarine Letters 2020 40:1, 40(1), 1-33. https://doi.org/10.1007/S00367-019-00631-W

Nelson, J. S., Grande, T. C., \& Wilson, M. V. (2016). Fishes of the World. John Wiley \& Sons.

Pimentel, C. R., Andrades, R., Ferreira, C. E. L., Gadig, O. B. F., Harvey, E. S., Joyeux, J.-C., \& Giarrizzo, T. (2020). BRUVS reveal locally extinct shark and the way for shark monitoring in Brazilian oceanic islands. Journal of Fish Biology, 96(2), 539-542. https://doi.org/10.1111/JFB.14228

Pinheiro, H. T., Bernardi, G., Simon, T., Joyeux, J.-C., Macieira, R. M., Gasparini, J. L., Rocha, C., \& Rocha, L. A. (2017). Island biogeography of marine organisms. Nature 2017 549:7670, 549(7670), 82-85. https://doi.org/10.1038/nature23680

Pinheiro, H. T., Macena, B., Francini-Filho, R. B., Ferreira, C., Albuquerque, F. V., Bezerra, N., Carvalho-Filho, A., Ferreira, R., Luiz, O. J., Mello, T. J., Mendonça, S. A., Nunes, D. M., Pimentel, C. R., Pires, A., SoaresGomes, A., Viana, D. L., Hazin, F., \& Rocha, L. A. (2020). Fish biodiversity of Saint Peter and Saint Paul's Archipelago, Mid-Atlantic Ridge, Brazil: new records and a species database. Journal of fish biology, 97(4), 1143-1153. https://doi.org/10.1111/jfb.14484

Pinsky, M. L., Eikeset, A. M., McCauley, D. J., Payne, J. L., \& Sunday, J. M. (2019). Greater vulnerability to warming of marine versus terrestrial ectotherms. Nature, 569(7754), 108-111.

https://doi.org/10.1038/s41586-019-1132-4

Ribeiro, A. O., Caires, R. A., Mariguela, T. C., Pereira, L. H., Hanner, R., \& Oliveira, C. (2012). DNA barcodes identify marine fishes of São Paulo State, Brazil. Molecular ecology resources, 12(6), 1012-1020. https://doi.org/10.1111/1755-0998.12007

Rock, J., Costa, F. O., Walker, D. I., North, A. W., Hutchinson, W. F., \& Carvalho, G. R. (2008). DNA barcodes of fish of the Scotia Sea, Antarctica indicate priority groups for taxonomic and systematics focus. Antarctic Science, 20(3), 253-262. https://doi.org/10.1017/S0954102008001120

Shaw, K. L., \& Gillespie, R. G. (2016). Comparative phylogeography of oceanic archipelagos: Hotspots for inferences of evolutionary process. Proceedings of the National Academy of Sciences of the United 
States of America, 113(29), 7986-7993. https://doi.org/10.1073/pnas.1601078113

Searle, R. (2013). Mid-Ocean Ridges. Cambridge: Cambridge University Press.

doi:10.1017/CBO9781139084260

Shokralla, S., Hellberg, R., Handy, S. et al. (2015). A DNA Mini-Barcoding System for Authentication of Processed Fish Products. Sci Rep 5, 15894. https://doi.org/10.1038/srep15894

Singer, G.A.C., Fahner, N.A., Barnes, J.G. et al. (2019). Comprehensive biodiversity analysis via ultra-deep patterned flow cell technology: a case study of eDNA metabarcoding seawater. Sci Rep 9, 5991. https://doi.org/10.1038/s41598-019-42455-9

Soares, M. de O., \& Lucas, C. C. (2018). Towards large and remote protected areas in the South Atlantic Ocean: St. Peter and St. Paul's Archipelago and the Vitória-Trindade Seamount Chain. Marine Policy, 93, 101-103. https://doi.org/10.1016/J.MARPOL.2018.04.004

Stat, M., Huggett, M. J., Bernasconi, R., DiBattista, J. D., Berry, T. E., Newman, S. J., ... \& Bunce, M. (2017). Ecosystem biomonitoring with eDNA: metabarcoding across the tree of life in a tropical marine environment. Scientific Reports, 7(1), 1-11. https://doi.org/10.1038/s41598-017-12501-5

Steinke, D., deWaard, J. R., Gomon, M. F., Johnson, J. W., Larson, H. K., Lucanus, O., Moore, G. I., Reader, S., \& Ward, R. D. (2017). DNA barcoding the fishes of Lizard Island (Great Barrier Reef). Biodiversity Data Journal, 5(5). https://doi.org/10.3897/BDJ.5.E12409

Steinke, D., Zemlak, T. S., Boutillier, J. A., \& Hebert, P. D. N. (2009). DNA barcoding of Pacific Canada's fishes. Marine Biology 2009 156:12, 156(12), 2641-2647. https://doi.org/10.1007/S00227-009-1284-0

Sultana, S., Ali, M. E., Hossain, M., Asing, Naquiah, N., \& Zaidul, I. (2018). Universal mini COI barcode for the identification of fish species in processed products. Food research international (Ottawa, Ont.), 105, 19-28. https://doi.org/10.1016/j.foodres.2017.10.065

Reuter, J. A., Spacek, D. V., \& Snyder, M. P. (2015). High-throughput sequencing technologies. Molecular cell, 58(4), 586-597. https://doi.org/10.1016/j.molcel.2015.05.004

Russo, T., Maiello, G., Talarico, L., Baillie, C., Colosimo, G., D'Andrea, L., Di Maio, F., Fiorentino, F., Franceschini, S., Garofalo, G., Scannella, D., Cataudella, S., \& Mariani, S. (2021). All is fish that comes to the net: metabarcoding for rapid fisheries catch assessment. Ecological applications: a publication of the Ecological Society of America, 31(2), e02273. https://doi.org/10.1002/eap.2273

Taberlet, P., Coissac, E., Hajibabaei, M. And Rieseberg, L.H. (2012), Environmental DNA. Molecular Ecology, 21: 1789-1793. https://doi.org/10.1111/j.1365-294X.2012.05542.x

Taberlet, P., Bonin, A., Zinger, L., \& Coissac, E. (2018). Environmental DNA: For Biodiversity Research and Monitoring. Oxford University Press USA - OSO. 
Thomsen, P. F., \& Willerslev, E. (2015). Environmental DNA-An emerging tool in conservation for monitoring past and present biodiversity. Biological conservation, 183, 4-18.

https://doi.org/10.1016/j.biocon.2014.11.019

UNESCO. (2021). World Heritage Centre - The Mid-Atlantic Ridge. Retrieved July 20, 2021, from https://whc.unesco.org/en/activities/504/

Vaske, T., Jr, Lessa, R.P., de Nóbrega, M., Montealegre-Quijano, S., Marcante Santana, F. and Bezerra, J.L., Jr (2005), A checklist of fishes from Saint Peter and Saint Paul Archipelago, Brazil. Journal of Applied Ichthyology, 21: 75-79. https://doi.org/10.1111/j.1439-0426.2004.00600.x

Viana, D., Hazin, F. \& Souza, M. (2009) O Arquipélago de São Pedro e São Paulo: 10 Anos de Estação Científica. Brasília, DF: SECIRM, 348 p.

Viana, D. F., Hazin, F. H. V., Andrade, H. A., Nunes, D. M., \& Viana, D. de L. (2015). Fisheries in the Saint Peter and Saint Paul archipelago: 13 years of monitoring. B. Inst. Pesca, 239-248.

http://www.pesca.sp.gov.br/41_2_239-248.pdf

Viana, D., Hazin, F., Andrade, H., Nunes, D., \& Viana, D. (2018). Fisheries in the Saint Peter and Saint Paul Archipelago: 13 years of monitoring. Boletim Do Instituto De Pesca, 41(2), 239 - 248. Retrieved from https://www.pesca.sp.gov.br/boletim/index.php/bip/article/view/373

Ward, R. D., Zemlak, T. S., Innes, B. H., Last, P. R., \& Hebert, P. D. N. (2005). DNA barcoding Australia's fish species. Philosophical Transactions of the Royal Society B: Biological Sciences, 360(1462), 1847. https://doi.org/10.1098/RSTB.2005.1716

Ward, R. D., Hanner, R., \& Hebert, P. D. N. (2009). The campaign to DNA barcode all fishes, FISH-BOL. Journal of Fish Biology, 74(2), 329-356. https://doi.org/10.1111/J.1095-8649.2008.02080.X

Ward R. D. (2012). FISH-BOL, a case study for DNA barcodes. Methods in molecular biology (Clifton, N.J.), 858, 423-439. https://doi.org/10.1007/978-1-61779-591-6_21

Wangensteen, O. S., Palacín, C., Guardiola, M., \& Turon, X. (2018). DNA metabarcoding of littoral hardbottom communities: high diversity and database gaps revealed by two molecular markers. PeerJ, 6 , e4705. https://doi.org/10.7717/peerj.4705

Xu, L., van Damme, K., Li, H., Ji, Y., Wang, X., \& Du, F. (2019). A molecular approach to the identification of marine fish of the Dongsha Islands (South China Sea). Fisheries Research, 213, 105-112. https://doi.org/10.1016/J.FISHRES.2019.01.011

Yang, L., Tan, Z., Wang, D. et al. (2014). Species identification through mitochondrial rRNA genetic analysis. Sci Rep 4, 4089. https://doi.org/10.1038/srep04089 
Yu, D.W., Ji, Y., Emerson, B.C., Wang, X., Ye, C., Yang, C. and Ding, Z. (2012), Biodiversity soup: metabarcoding of arthropods for rapid biodiversity assessment and biomonitoring. Methods in Ecology and Evolution, 3: 613-623. https://doi.org/10.1111/j.2041-210X.2012.00198.x

Zhang, J., Chiodini, R., Badr, A., \& Zhang, G. (2011). The impact of next-generation sequencing on genomics. Journal of genetics and genomics $=$ Yi chuan xue bao, 38(3), 95-109.

https://doi.org/10.1016/j.jgg.2011.02.003

Zhang, J. bin, \& Hanner, R. (2011). DNA barcoding is a useful tool for the identification of marine fishes from Japan. Biochemical Systematics and Ecology, 39(1), 31-42.

https://doi.org/10.1016/J.BSE.2010.12.017

\section{Figures}

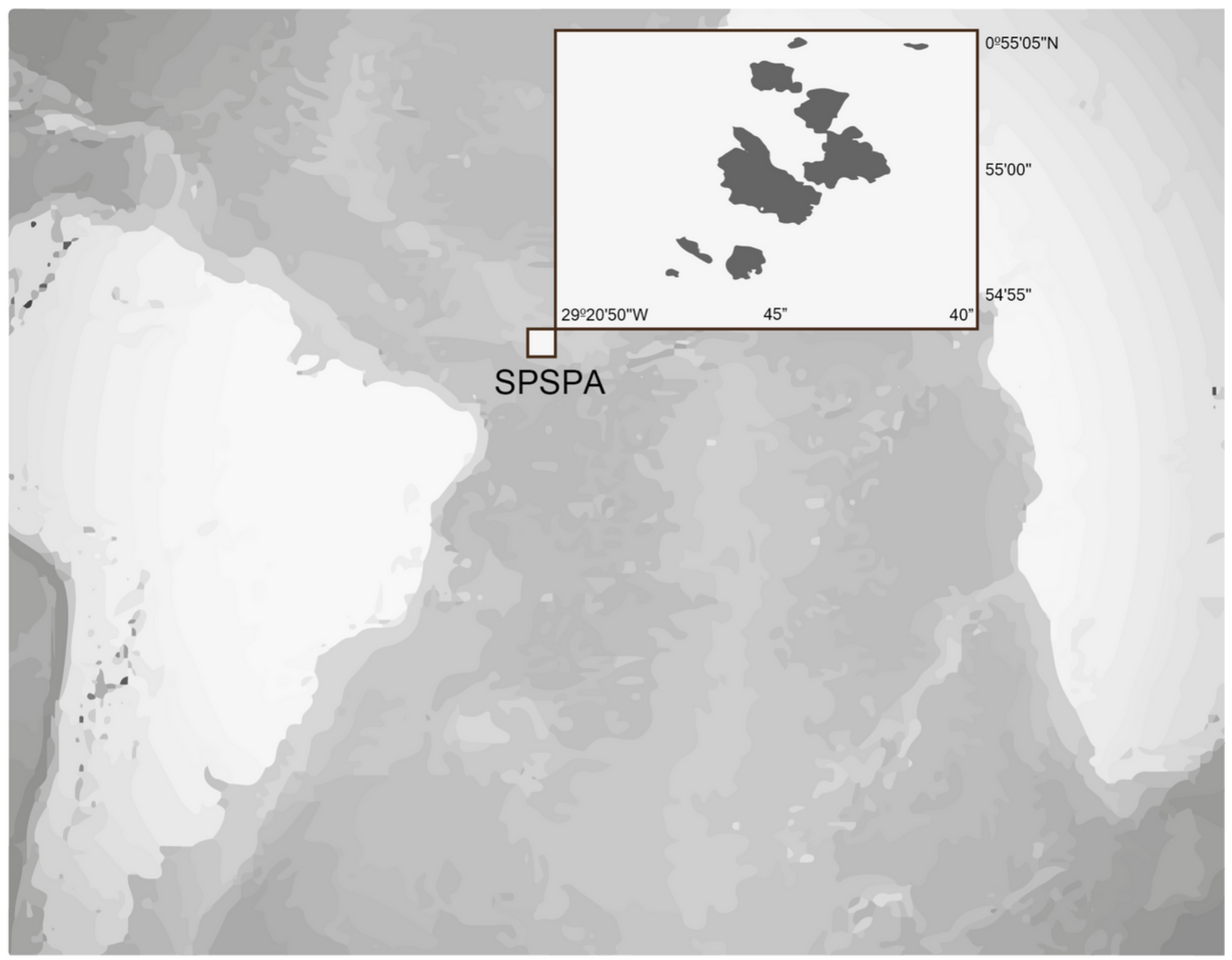

Figure 1 
Saint Peter and Saint Paul Archipelago (SPSPA) in a map showing its geographical location (white square) in the Mid-Atlantic Ridge

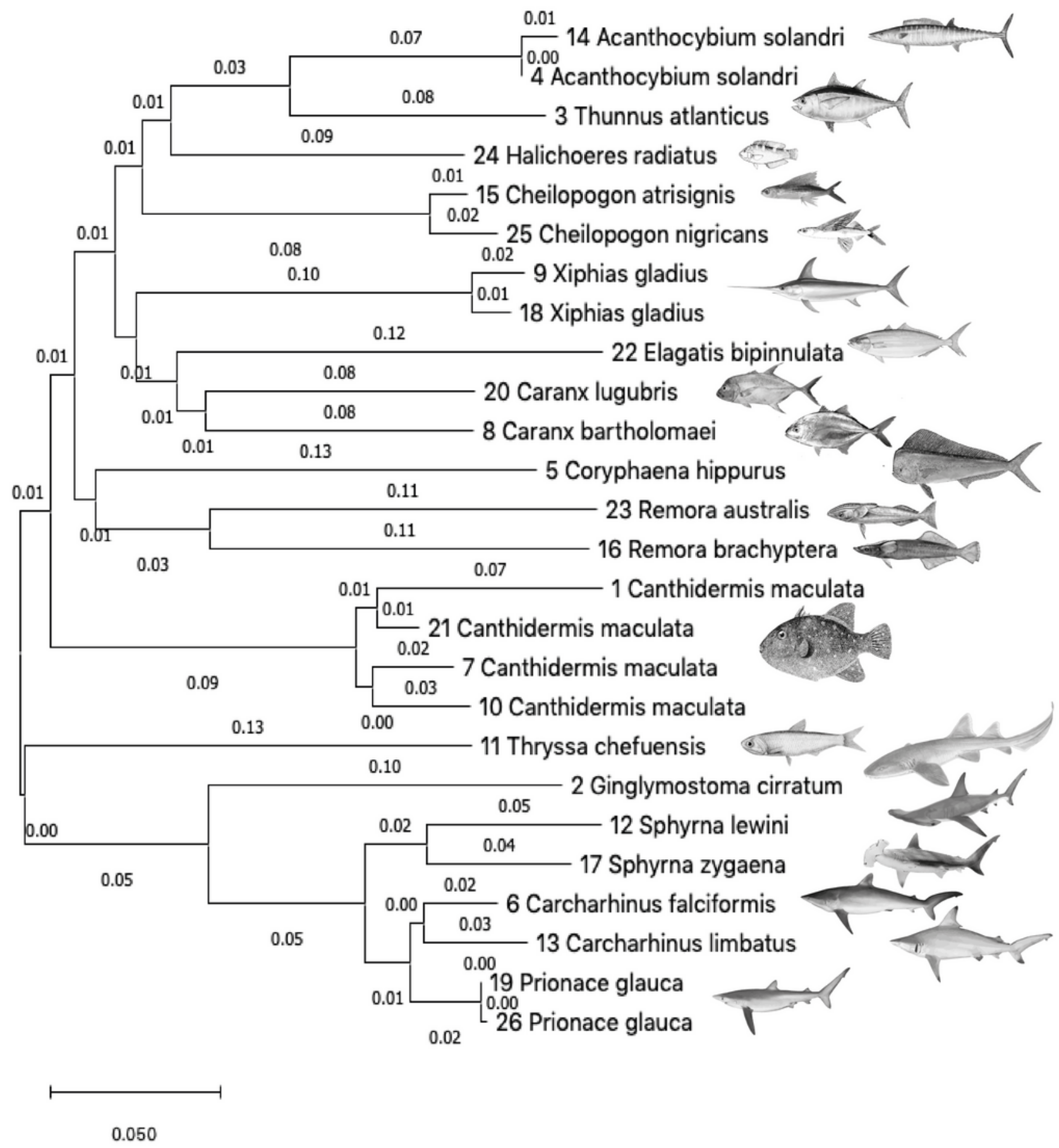

Figure 2

Neighbor-Joining Tree of the Saint Peter and Saint Paul Archipelago surveyed fish species labeled with substitutions per site 